Journal of Social Sciences 4 (4): 246-250, 2008

ISSN 1549-3652

(C) 2008 Science Publications

\title{
Personal Characteristics Affecting Agricultural Extension Workers' Job Satisfaction Level
}

\author{
${ }^{1}$ Ali Asadi, ${ }^{1}$ Fereshteh Fadakar, ${ }^{1}$ Zahra Khoshnodifar, \\ ${ }^{1}$ Seyyed Mahmoud Hashemi and ${ }^{2}$ Gholamhossein hosseininia \\ ${ }^{1}$ Department of Agricultural Extension and education, \\ College of Agriculture, Tehran University, Karaj, Iran \\ ${ }^{2}$ Expert of Extension, Ministry of cooperatives, Tehran
}

\begin{abstract}
Problem Statement: One of the closely associated concepts with performance of an organization is job satisfaction. The purpose of this study was to investigate the relationship between personal characteristics and job satisfaction. Approach: A survey of 52 extension workers was conducted in Fars Province, southern Iran. To collect data, a questionnaire including Bray field and Rothe Job Satisfaction Index was used. Results: The study found that the majority of the extension workers $(65.5 \%)$ belonged to intermediate level of job satisfaction, followed by 29.1 and $5.5 \%$ belonging to high and low level of job satisfaction, respectively. Regression results also indicated that the full model was moderately successful, explaining $45 \%$ of the variances in the job satisfaction. Two independent variables that accounted for the explained variances were monthly salary $(27 \%)$ and marital status (18\%). Conclusions/Recommendations: Administration should conduct a periodic needs assessment to determine the level of job satisfaction of personnel and identify methods for increasing satisfaction based on these findings.
\end{abstract}

Key words: Job satisfaction, personal characteristics, extension workers, managers, Iran

\section{INTRODUCTION}

In Iran, 23 million people are earning directly from agriculture and nearly 3.5 million of active population is working in this sector ${ }^{[1]}$. Role of extension and education of agriculture is vital in the agricultural development and can't be gainsaid $^{[23]}$. Despite the efforts with regards to agricultural development and supporting farmers to improve their competencies in different aspects of their jobs by Iran Agricultural Extension Organization (AES), there are indications that the efficiency and the quality of the support provided by AES have not been enough to serve the farmers' needs ${ }^{[9]}$. Also AES in Iran is suffering from malfunctions in the area of human resource management and development ${ }^{[10]}$. Moreover, the challenge of working for extension is included job positions are multidimensional, often including new projects before the old are completed. Frustration and stress are continuous due to the slowness of finishing many projects. Time frames are much longer due to a variety of factors, including a lack of funding, a long approval process, differences between agent and administrative values, and philosophical differences ${ }^{[12]}$.

One of the closely associated concepts with performance of an organization is job satisfaction. Job satisfaction is defined as all the feelings that an individual has about his/her job ${ }^{[22]}$. Several studies have shown the impacts of job satisfaction on other essential factors of organizations. Bowran and Todd ${ }^{[3]}$ asserted that "behavioral and social science research suggests that job satisfaction and job performance are positively correlated. A better understanding of job satisfaction and factors associated with it helps managers guide employee's activities in a desired direction". Rownowski and Hulin ${ }^{[20]}$ suggested that the most useful information to have about an employee in an organization is a valid measure of their overall level of job satisfaction. Job satisfaction factors allow individuals to reach their psychological potential. To find relationships among some important factors in organizations, Heskett et $a l^{[8]}$ established a framework in which internal service quality drives employee satisfaction, which, in turn, drives employee performance that generates service quality.

Corresponding Author: Hashemi, S.M., Department of Agricultural Extension and Education, College of Agriculture, Tehran University, Karaj, Iran Tel: +98 9173295387 Fax: +98 2612818709 


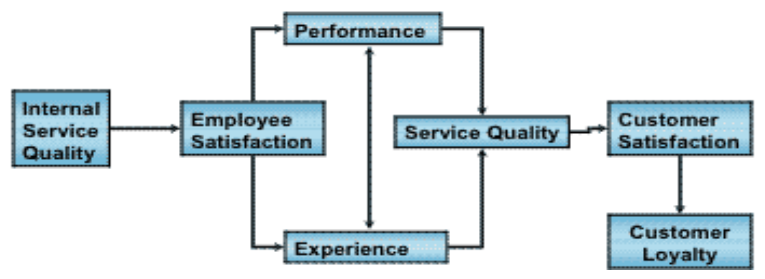

Fig. 1: Service-profit model ${ }^{[24]}$

Finally, service quality drives customer satisfaction that leads to customer retention and profits (Fig. 1). Based on this context as well as to know totally most of the analyses dealing with the relationship between job satisfaction and other variables of interest have been based on data collected in Western countries ${ }^{[13]}$ and studies of Iranian agricultural extension workers' job satisfaction are rare, we can come to this point: knowing the factors related to extension workers' job satisfaction can be of paramount topics.

Job satisfaction in extension is dependent on many factors ${ }^{[6]}$.

Empirical literature suggests that Job satisfaction is related to a number of organizational, professional and personal variables ${ }^{[14]}$. Research results also indicated that many personal characteristics affect job satisfaction in many different and complex ways ${ }^{[11]}$. This study was designed to identify extension workers' personal characteristics and their relationships with job satisfaction.

Purpose and objectives: The main purpose of this research was to investigate the relationship between personal characteristics and job satisfaction.

Of particular interests were to:

- Study the personal traits of extension workers in context of job satisfaction

- Measure the level of job satisfaction of extension workers and

- Explore the extent to which certain personal characteristics predict extension workers' job satisfaction

\section{METRIALS AND METHODS}

Population and sample: The study's population and sample consisted of all the Agricultural Organization extension workers from Fars province southern Iran (Fig. 2). This is one of the leading provinces in agricultural production ${ }^{[7]}$.

Instrument: A variety of scales and self-developed questionnaires have been employed to measure job satisfaction. This study employed a questionnaire

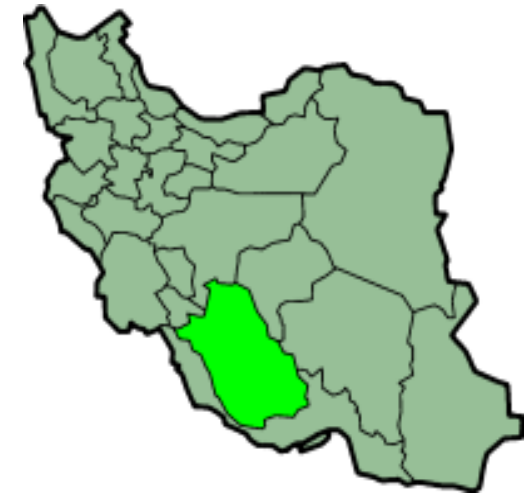

Fig. 2: Location of the study area. [Iran country (Fars province)]

comprising Job Satisfaction Scale to measure job satisfaction using Brayfield and Rothe Job Satisfaction Index ${ }^{[4]}$. This scale is a self-report instrument that measures job satisfaction across 20 different items. Respondents were instructed to indicate the extent of their agreement with each item on a fivepoint scale ranging "strongly disagree, disagree, neither disagree nor agree, agree, strongly agree.

Following the distributing of the questionnaire, 55 out of 69 questionnaires were returned; representing a response rate of 0.79 . Reliability of the questionnaire was measured by computing of Cronbach's Alpha coefficient, the measure of internal consistency, this coefficient for job satisfaction was 0.84 which indicates the acceptable level of reliability ${ }^{[18]}$. To evaluate validity of this instrument, questionnaire was assessed by some Tehran university agricultural extension and education department scientific board members.

Data analysis: In this research, descriptive and inferential statistics were used to analyze collected data. Descriptive statistics were included frequency values (mean, standard deviation and so forth) and inferential statistics were included regression procedures, correlation coefficients calculations. In preparation for the stepwise regression analysis, variables at the nominal level were coded into a set of dummy variables $^{[17]}$. All data were analyzed using the SPSS for Windows, version 11.5.0 and Microsoft Excel.

\section{RESULTS}

As shown in Table 1 the sample used in the present study were 41 men and 14 women. The mean age was about 40 years. The vast majority of respondent were married $(89.1 \%), 10.5 \%$ were single. Majority Of the respondents had bachelor degrees (50.9\%), 12.7\% were 
with diploma degree, $21.8 \%$ were with associate degrees, and $14.5 \%$ hold master or $\mathrm{PhD}$ degrees. Majority of the respondents were involved in secure jobs (54.6\%) and 45.4\% were temporary employees.

Extension workers' service year distributed almost evenly among the five categories ranging from "Lower than 5 years" to "21 and over". Monthly salary of extension workers ranged from 180000-500000 with mean value of 363000 .

Table 2 shows the overall index of job satisfaction which is identified as the mean score obtained from a 20-item questionnaire.

A total score of $0-50$ is interpreted as low job satisfaction, while 70 and over is considered to represent high job satisfaction.

In Table 3 the majority of the extension workers $(65.5 \%)$ belonged to intermediate level of job satisfaction, followed by 29.1 and $5.5 \%$ belonging to high and low level of job satisfaction, respectively (Table 3).

In Table 4, there was a non-significant relationship between age and job satisfaction $(\mathrm{r}=-0.05)$, service years and job satisfaction $(\mathrm{r}=-0.01)$ and working hours per week and job satisfaction $(r=-0.14)$. On the other hands, there was a significant negative relationship between monthly salary and job satisfaction $(r=-0.53)$.

Comparison of Extension workers by some personal traits indicated that there was a significant difference between single and married extension workers on the level of job satisfaction (married > single). Meanwhile there were no significant differences between different categories of job tenure, years of education, and sex (indicated in the Table 5) on the level of job satisfaction (Table 5).
In this research for identification of personal traits associated with job satisfaction, a regression procedure was used (Table 6). For extension workers regression procedures indicated that the full model was moderately successful, explaining $45 \%$ (Adjusted $\mathrm{R}^{2}=0.45$ ) of the variance, in job satisfaction. Two independent variables that accounted for the explained variance were monthly salary $(27 \%)$ and marital status (18\%).

Table 1: Personal traits of agricultural extension workers

\begin{tabular}{llccc}
\hline Variable Name & & frequency & percentage & SD/Mean \\
\hline \multirow{4}{*}{ Age } & $25-30$ & 5 & 9.1 & $7.02 / 39.6$ \\
& $31-35$ & 12 & 21.8 & \\
& $36-40$ & 13 & 23.6 & \\
& $41-45$ & 12 & 21.8 & \\
Sex & $46-50$ & 8 & 14.5 & \\
Years of & 51 and above & 5 & 9.1 & \\
Education & Male & 41 & 74.5 & \\
& Female & 14 & 25.5 & \\
& Diploma & 7 & 12.7 & \\
& Associate & 12 & 21.8 & \\
Marital status & Bachelor & 28 & 50.9 & \\
Service years & Master degree & 8 & 14.5 & \\
& and higher & & & \\
& Single & 6 & 10.5 & \\
& Married & 49 & 89.1 & \\
& Up to 5 years & 8 & 14.5 & \\
& $7.38 / 13.98$ & & & \\
& $10-$ May & 11 & 20 & \\
& $15-$ Nov & 15 & 27.3 & \\
Job tenure & $16-20$ & 9 & 16.4 & \\
& 21 and above & 12 & 21.8 & \\
& Permanent & 30 & 54.6 & \\
Monthly salary & Temporary & 25 & 45.4 & \\
(Toman*) & $180-245$ & 2 & 3.6 & $1.2 / 363000$ \\
& $246-310$ & 8 & 14.5 & \\
& $311-375$ & 19 & 34.5 & \\
& $376-440$ & 21 & 38.2 & \\
& $441-500$ & 5 & 9.1 & \\
\hline
\end{tabular}

*One of currency units in Iran (1 US Dollar $=949.58$ Iranian Toman)

Table 2: Job satisfaction index $(\mathrm{N}=55)$

\begin{tabular}{lll}
\hline Job Satisfaction Questions & Mean & SD \\
\hline My job is pretty interesting & 2.85 & 1.193 \\
I like my job better than the average worker does & 2.89 & 1.286 \\
It seems that my friends are more interested in their jobs & 2.91 & 1.236 \\
I am adequately paid for the job I do & 3.09 & 1.251 \\
I feel fairly well-satisfied with my present job & 3.18 & 3.18 \\
I am often bored with my job & 3.20 & 1.307 \\
I enjoy my work more than my leisure time & 3.24 & 1.056 \\
My job has a fair (impartial) promotion policy & 3.27 & 1.186 \\
My job is interesting enough to keep me from being bored & 3.29 & 1.162 \\
I feel that I am happier in my work than most other people & 3.33 & 1.301 \\
I consider my job rather unpleasant & 3.36 & 1.187 \\
My job is like a hobby to me & 3.36 & 1.393 \\
Each day of work seems like it will never end & 3.38 & 1.112 \\
I find real enjoyment in my work & 3.42 & 1.209 \\
Most days I am enthusiastic about my work & 3.53 & 1.243 \\
I am satisfied with my job for the time being & 3.53 & 1.184 \\
I am disappointed that I took this job & 3.53 & 1.230 \\
Most of the time I have to force myself to go to work & 3.76 & 1.168 \\
I definitely dislike my work & 3.82 & 1.105 \\
I feel my job is more interesting than others I could get & & 1.038 \\
\hline
\end{tabular}


Table 3: Extension workers' level of job satisfaction

\begin{tabular}{lcc}
\hline Level of job satisfaction & Frequency & Percentage \\
\hline Low (Up to 50 points) & 3 & 5.5 \\
Intermediate (50-70 points) & 36 & 65.5 \\
High (above 70 points) & 16 & 29.1 \\
Total & 55 & 100 \\
\hline
\end{tabular}

Table 4: Correlation analysis between job satisfaction and some independent variables

\begin{tabular}{llc}
\hline Independent variable & Correlation coefficient (Pearson correlation) \\
\hline Age & -0.05 & $\mathrm{~ns}$ \\
Service years & -0.01 & $\mathrm{~ns}$ \\
Monthly salary & 0.53 & $* *$ \\
Working hours per day & -0.14 & $\mathrm{~ns}$ \\
\hline
\end{tabular}

* Significant at $\mathrm{p}<0.05,{ }^{* *}$ Significant at $\mathrm{p}<0.01$

Table 5: Comparison of Extension workers' level of job satisfaction by some variables

\begin{tabular}{llccc}
\hline Variable & Mean rank & & \multicolumn{2}{c}{$\begin{array}{c}\text { Mann whitney/ } \\
\text { kruskal-wallis value }\end{array}$} \\
\hline Job tenure & Permanent & 54.14 & 1.6 & $\mathrm{~ns}$ \\
Years of & Temporary & 49.67 & & $\mathrm{~ns}$ \\
Education & Diploma & 25.79 & 0.6 & \\
& Associate & 25.83 & & \\
& Bachelor & 28.66 & & \\
& Master degree & 30.88 & & $\mathrm{~ns}$ \\
Sex & and higher & & & \\
& Male & 26.94 & 243.5 & \\
Marital status & Female & 31.11 & \multirow{2}{*}{28.5} & $*$ \\
& Single & 8.25 & & \\
& Married & 30.42 & &
\end{tabular}

* Significant at $\mathrm{p}<0.05,{ }^{* *}$ Significant at $\mathrm{p}<0.01$

Table 6: Regression analysis for personal traits associated with extension workers' job satisfaction

\begin{tabular}{|c|c|c|c|c|c|c|c|c|}
\hline Step & variable & $\mathrm{B}$ & S.E & Beta & $\begin{array}{l}\text { Significant } \\
\text { level }\end{array}$ & $\mathrm{R}$ & $\mathrm{R}^{2}$ & $\begin{array}{l}\text { Adjusted } \\
\mathrm{R}^{2}\end{array}$ \\
\hline \multirow[t]{3}{*}{1} & constant & 95.94 & 6.49 & 0.53 & 0 & & & \\
\hline & Monthly & -0.82 & 0.018 & & 0 & & & \\
\hline & $\begin{array}{l}\text { Salary } \\
\text { constant }\end{array}$ & 85.56 & 6.16 & & 0 & & & \\
\hline \multirow{2}{*}{2} & Monthly & -0.85 & 0.015 & 0.56 & 0 & 0.53 & 0.29 & 0.27 \\
\hline & $\begin{array}{l}\text { Salary } \\
\text { Marital } \\
\text { Status }\end{array}$ & 12.95 & 3.05 & 0.427 & 0 & 0.68 & 0.47 & 0.45 \\
\hline
\end{tabular}

In other words, extension workers with higher amounts of monthly salary and married extension workers, in two cases, there was more likely to have higher level of job satisfaction. However there was a relationship between dependent variable (Y) and independent variables (following equation):

$\mathrm{Y}=85.569-0.560 \mathrm{X} 1$ (Monthly salary) $+0.427 \mathrm{X} 2$ (Marital status)

\section{DISCUSSION}

The index items most suggesting negative job satisfaction were low salary and job's unfair promotion policy, respectively. As mentioned, there was a nonsignificant relationship between age and job satisfaction (this is in line with the study conducted by Singh and Singh $^{[21]}$ ), service years and job satisfaction (this is what happened in the study carried out by ${ }^{[2]}$ and working hours per week and job satisfaction (this is in consistent with results of study conducted by $\left.{ }^{[15]}\right)$. On the other hands, there was a significant negative relationship between monthly salary and job satisfaction (this is in line with the study conducted in Kurdistan, Iran by $\left.{ }^{[19]}\right)$. Contribution of personal traits was 45 percent in the explaining of variances in the job satisfaction indicating remaining variances in the job satisfaction was explained by other factors such as organizational, professional variables ${ }^{[14]}$.

\section{COCLUSION}

Job satisfaction is possibly the most studied attitude in organizational behavior ${ }^{[5]}$, But because Job satisfaction tends to vary from country to country depending on job-culture fit (Chimanikire et al.) and most of the analyses dealing with the relationship between job satisfaction and other variables of interest have been based on data collected in Western countries $^{[13]}$, This study aimed at investigating the relationship between job satisfaction and personal traits among extension workers which have necessary roles in Iran and other developing countries with important contribution of agriculture and rural population in the country development. The study confirmed personal traits have considerable impacts on extension workers' level of Job satisfaction. In other words, contribution of personal traits was 45 percent in the explaining of variances in the job satisfaction indicating remaining variances in the job satisfaction was explained by other factors such as organizational, professional variables ${ }^{[14]}$. The index items most suggesting negative job satisfaction were low salary and job's unfair promotion policy, respectively. Contribution of monthly salary and marital status was important in the explaining level of extension workers' job satisfaction. Therefore, administration should conduct a periodic needs assessment to determine the level of job satisfaction of personnel and identify methods for increasing satisfaction ${ }^{[16]}$ based on these findings.

\section{ACKNOWLEDGEMENT}

The authors gratefully acknowledge the scientific board members of the Department of Agricultural Extension and Education, Tehran University for their valuable insights and guidance for carrying out this study and compiling the questionnaire of the study.

\section{REFERENCES}

1. Asadi, A. and A. Shams, 2003. Some challenges on the way of agricultural development in Iran. Jihad Mag., 23: 48-56 (In Farsi). 
2. Bedeian, A.G., G.R. Farris and K.M. Kacmar, 1992. Age, tenure and job satisfaction: A tale of two perspectives. J. Vocat. Behav, 40: 33-48. http://eric.ed.gov/ERICWebPortal/custom/portlets/ recordDetails/detailmini.jsp?_nfpb=true\&_\&ERIC ExtSearch SearchValue 0=EJ440655\&ERICExtS earch_SearchType_0=no\&accno=EJ440655.

3. Bowran, J. and K. Todd, 1999. Job stressor and job satisfaction in a major metropolitan public EMS service. Prehospital Disaster Med., 14: 236-239. http://www.ncbi.nlm.nih.gov/pubmed/10915409

4. Brayfield, A.H. and H.F. Rothe, 1951. An index of job satisfaction. J. Applied Psychol., 35: 307-311. Doi: 10.1037/h0055617

5. Cranny, C.J., P.C. Smith and E.F. Stone, 1992. Job Satisfaction: How People Feel about Their Jobs and How it Affects Their Performance. 1st Edn., Lexington Books, New York, USA., ISBN-10: 066921289X, pp: 296.

6. Ensle, K.M., 2005. Burnout: How does extension balance job and family? J. Extension, 43. http://www.joe.org/joe/2005june/a5.shtml.

7. Hassanshahi, H., H. Irvani, K. Kalantari and A. Rezaei, 2008. Analysis of natural resources management assets in the Agricultural Production Cooperatives (APCs) in Fars Province, Iran. Am. Eurasian J. Sustain. Agric., 2: 61-68. http://www.aensi.org/aejsa/2008/61-68.pdf.

8. Heskett, J.L., T.O. Jones, G. Loveman, W.E. Jr. Sasser and L.A. Schlesinger, 1994. Putting the service-profit chain to work. Harvard Bus. Rev., 72: 164-174. http://people.exeter.ac. uk/icln201/research/papers/samplecritique.pdf.

9. Karbasioun, M., H. Biemans and M. Mulder, 2007. The supporting role of the Agricultural Extension Services (AES) and implications for Agricultural Extension Instructors (AEIs) as perceived by farmers in Esfahan, Iran. J. Int. Agric. Extens. Educ., 14: 31-44. http://www.aiaee.org/archive/ Vol-14.1.pdf.

10. Karbasioun, M., S. Mirzaei and M. Mulder, 2005. Informal Technical and Vocational Training Programs (ITVTP) and farming in the province of Isfahan, Iran. J. Int. Agric. Educ. Extens., 12: 33-43. http://66.102.1.104/scholar?hl=en\&lr $=\& q=$ cache:-KA56HqM7LcJ:library.wur.nl/wasp/ bestanden/LUWPUBRD 00343932 A502 001.pdf + Karbasioun, + M., + S.+Mirzaei+and+M.+Mulder, + 2005.

11. Koustelios Athanasios, D., 2001. Personal characteristics and job satisfaction of Greek teachers. Int. J. Educ. Manage., 15: 354-358. DOI: 10.1108/EUM0000000005931.
12. Kutilek, L.M., N.L. Conklin and G. Gunderson, 2002. Investing in the future: Addressing work/life issues of employees. J. Extens., 40. http:// www.joe.org/joe/2002february/a6.html.

13. Lincoln, J.R. and A.L. Kalleberg, 1990. Culture, Control and Commitment: A Study of Work Organization and Work Attitudes in the United States and Japan. 1st Edn., Cambridge University Press, New York, ISBN: 0521428661.

14. Lu, H., A. While and L. Barriball, 2005. Job satisfaction among nurses: A literature review. Int. J. Nurs. Stud., 42: 211-227. DOI: 10.1016/j.ijnurstu.2004.09.003.

15. Maity, M., B.S. Malik, M.K. Mandal, Gautam and A. Roy Choudhary, 2007. Determinants of job satisfaction among livestock development assistants of West Bengal, India. Livestock Res. Rural Dev., 19. http://www.cipav.org.co/lrrd/ lrrd19/6/mait19082.htm.

16. Mallio, A., 1990. Extension staff satisfaction. J. Exten., 28. http://www.joe.org/joe/1990summer /rb5.html

17. Norusis, M.J., 1990. SPSS Introductory Statistics Student Guide. SPSS Inc., Chicago, IL.

18. Nunnally, J.C., 1978. Psychometric Theory. 2nd Edn., McGraw-Hill Company, New York, USA., ISBN: 13: 978-0070478497, pp: 245.

19. Rezvanfar, A. and H. Vaisy, 2006. Job satisfaction amongst agricultural extension personnel in Kurdistan Province of Iran. South Afr. J. Agric. Extens., 35: 176-187. http://www.ajol.info/ viewarticle.php?id $=41926$.

20. Rownowski, M. and C. Hulin, 1992. The Scientific Merit of Valid Measures of General Constructs with Special Reference to Job Satisfaction and Job Withdrawal. In: Job Satisfaction: How People Feel about their Jobs and How it Affects their Performances, Cranny, C.J., P.C. Smith and E.F. Stone (Eds.). Lexington Books, New York, USA., ISBN: 13: 978-0669212891.

21. Singh, S. and A. Singh, 1980. The effect of certain social and personal factors on job. Psychol. Stud., 25: 129-32.

22. Spector, P.E., 1997. Job Satisfaction: Application, Assessment, Causes and Consequences. 1st Edn., Sage Publications, Thousand Oaks, CA., ISBN: 10: 0761989234.

23. Tatum, Ch., 1995. Effects of system control and feedback variability on job performance and affective reactions. J. Human Perform., 89: 297-325. Doi: 10.1207/s15327043hup0804_3

24. Terry, B. D., and G.D. Israel, 2004.. Agent performance and customer satisfaction. J. Extension, 42. http://www.joe.org/joe/2004 december/a4.shtml 